\title{
25 Research Square \\ COVID patients encountered by a general surgeon- 6 unique scenarios.
}

\section{Dr. Sumita Jain}

SMS Medical college and Hospital, Jaipur

Dr. Deeksha Mehta ( $\nabla$ deeksha_doc@yahoo.co.in )

SMS Medical college and Hospital, Jaipur

Dr. Lakshman Aggarwal

SMS Medical college and Hospital, Jaipur

\section{Dr. Alka Goyal}

SMS Medical college and Hospital, Jaipur

Chandra Shekhar Sharma

SMS Medical college and Hospital, Jaipur

Dr. Naresh Kumar Mangalhara

SMS Medical college and Hospital, Jaipur

Dr. Yogendra Dadhich

SMS Medical college and Hospital, Jaipur

Dr. Somendra Bansal

SMS Medical college and Hospital, Jaipur

\section{Research Article}

Keywords:

Posted Date: September 17th, 2020

DOl: https://doi.org/10.21203/rs.3.rs-37602/v2

License: (c) (1) This work is licensed under a Creative Commons Attribution 4.0 International License.

Read Full License 


\section{Abstract}

The authors have requested that this preprint be withdrawn due to author disagreement.

\section{Full Text}

The authors have withdrawn this preprint from Research Square. 